Insight, part of a Special Feature on The influence of human demography and agriculture on natural systems in the Neotropics

\title{
The Roles and Movements of Actors in the Deforestation of Brazilian Amazonia
}

\author{
$\underline{\text { Philip M. Fearnside }}^{1}$
}

\begin{abstract}
Containing the advance of deforestation in Brazilian Amazonia requires understanding the roles and movements of the actors involved. The importance of different actors varies widely among locations within the region, and also evolves at any particular site over the course of frontier establishment and consolidation. Landless migrants have significant roles in clearing the land they occupy and in motivating landholders to clear as a defense against invasion or expropriation. Colonists in official settlements and other small farmers also are responsible for substantial amounts of clearing, but ranchers constitute the largest component of the region's clearing. This group is most responsive to macroeconomic changes affecting such factors as commodity prices, and also receives substantial subsidies. Ulterior motives, such as land speculation and money laundering, also affect this group. Drug trafficking and money laundering represent strong forces in some areas and help spread deforestation where it would be unprofitable based only on the legitimate economy. Goldminers increase the population in distant areas and subsequently enter the ranks of other groups. Work as laborers or debt slaves provides an important entry to the region for poor migrants from northeast Brazil, providing cheap labor to large ranches and a large source of entrants to other groups, such as landless farmers and colonists. Capitalized farmers, including agribusiness for soy production, have tremendous impact in certain areas, such as Mato Grosso. This group responds to commodity markets and provides justification for major infrastructure projects. Landgrabbers, or grileiros, are important in entering public land and beginning the process of deforestation and transfer of land to subsequent groups of actors. These include sawmill owners and loggers, who play an important role in generating funds for clearing by other groups, ranging from landless migrants to large ranchers. They also build endogenous roads, facilitating the entry of other actors. Future movements of actors will be influenced by major infrastructure plans, such as those for hydroelectric dams.
\end{abstract}

Policies for reducing deforestation must include removing motives for deforestation by stopping the practice of regularizing land claims and by cutting subsidies. The rule of law must be established throughout the region by completing the cadaster, or register, of land titles and by reinforcing command and control. Movement to the frontier needs to be discouraged by exercising restraint in approving infrastructure such as highways, and by creating and protecting conservation units. Economic alternatives to deforestation should be fostered by generating employment in source areas and in alternative migration destinations, by supporting sustainable uses of forest, by supporting alternative supply of domestic markets for products such as timber, and by rewarding the environmental services of standing forest.

Key Words: deforestation; migration; population; rainforest; ranching 


\section{INTRODUCTION}

Amazonian deforestation is one of the most serious environmental problems on Earth, with impacts ranging from emission of greenhouse gases to disruption of the regional water cycle and loss of biodiversity. Understanding the forces driving deforestation is a top priority because any changes in policies designed to contain deforestation are likely to fail if they are not based on realistic scenarios of how the social processes involved operate today and how they may change in the future. Migration is an important part of these processes. The effect of population is very flexible because cattle ranching (the main use of deforested land in Brazilian Amazonia) is an activity through which a tiny population of humans can have a tremendous impact on deforestation.

Deforestation is often modeled as a process whereby clearing either spreads out from highways at a fixed rate (e.g., Kirby et al. 2006, Laurance et al. 2001, 2002) or spreads at rates determined in a "demanddriven" fashion as a regional total that is then allocated to different locations based on "weights of evidence," or probabilities reflecting the attractiveness of each site based on such characteristics as distance to roads and soil quality (Soares-Filho et al. 2004, 2006). Although these approaches have been important in providing spatial representations of the probable future course of deforestation, a more detailed actor-based approach will be needed if the social processes underlying deforestation are to be understood and eventually modified to contain clearing.

Migration has much more impact on deforestation than does the vegetative growth (increase through reproduction) of any segment of the population. Migration involves not only the movement of people, but also the movement of investment. The type of actor that is moving into an area of forest is of primary importance in determining the rate of spread of deforestation. Types of actors cover a full range in terms of wealth, legality, and the intensive or extensive nature of their activities (Table 1). The present paper examines what we know about nine key groups of actors and their movements in Brazilian Amazonia: landless migrants ("sem terras"), colonists/small farmers, ranchers, drug traffickers/money launderers, goldminers (garimpeiros), laborers/debt slaves, capitalized farmers, landgrabbers (grileiros), and sawmill operators/loggers.

\section{ACTORS AND THEIR IMPACTS}

\section{Landless Migrants (“Sem Terras")}

Poor landless migrants arrive in the region from source areas such as the state of Maranhão; one component of this migration is seeking free land, and usually arrives as whole families (e.g., Trairão on the BR-163 Highway; Fig. 1). Another component arrives as unaccompanied men who often work as laborers rather than claiming land. In recent years, many of the migrants seeking land have become "sem terras," or members of organized groups such as the Movement of Landless Rural Workers (MST).

Migration from Maranhão has completely transformed the central portion of the state of Pará, centered on Marabá. This entire area is now degraded, including virtually every fragment of forest left in the deforested landscape (personal observation; see also Rede GEOMA 2003). The Carajás Railway, completed in 1985, has one passenger train per week (with heavily subsidized ticket prices) as a public-relations investment on the part of Companhia Vale do Rio Doce (CVRD), the formerly government-run company that operates both the Carajás iron mine and the $890-\mathrm{km}$ railway built to carry the ore to a port near São Luis, Maranhão (Fearnside 1986a). The steady arrival of up to 100 families a week in Marabá has supplied a virtually inexhaustible source of settlers and landless migrants to central Pará (Fearnside 2001a). Violent land conflicts have long been frequent (e. g., Schmink and Wood 1992, Simmons 2005). This violence gained public visibility with the El Dourado dos Carajás massacre in April 1996, when landless migrants were gunned down by military police. Of the 19 migrants killed, 13 were from Maranhão.

\section{Colonists/Small Farmers}

Movements of small farmers in the past have included migration to the Transamazon Highway from other regions, such as the semi-arid Northeast, in the early 1970s (Fearnside 1986b, Moran 1981, Smith 1982) and movement from Paraná to Rondônia facilitated by the BR-364 Highway in the early 1980s (Fearnside 1989a, Mesquita and Egler 1979). Many of these people were "colonists" ("colonos"), or settlers who are placed on lots in official settlement areas of various types. Others 
Table 1. Actors in Amazonian deforestation

\begin{tabular}{|c|c|c|c|c|}
\hline $\begin{array}{l}\text { Actor } \\
\text { number }\end{array}$ & $\begin{array}{l}\text { Actor } \\
\text { name }\end{array}$ & Main origin & Principal areas settled & Activities \\
\hline 1 & $\begin{array}{l}\text { Landless migrants } \\
\text { ("sem terras") }\end{array}$ & $\begin{array}{l}\text { Northeastern Brazil, } \\
\text { especially Maranhão }\end{array}$ & Southern Pará & Annual crops, pasture \\
\hline 2 & Colonists & $\begin{array}{l}\text { Northeastern Brazil, } \\
\text { especially Maranhão; } \\
\text { Paraná, Rio Grande } \\
\text { do Sul }\end{array}$ & $\begin{array}{l}\text { Transamazon Highway; } \\
\text { Rondônia }\end{array}$ & $\begin{array}{l}\text { Annual crops (rice, } \\
\text { maize, manioc), pasture }\end{array}$ \\
\hline 3 & Ranchers & $\begin{array}{l}\text { Southern, Center- } \\
\text { south, and Center- } \\
\text { west regions }\end{array}$ & $\begin{array}{l}\text { Northern Mato Grosso, } \\
\text { Southern Pará }\end{array}$ & Pasture \\
\hline 4 & $\begin{array}{l}\text { Drug traffickers/money } \\
\text { launderers }\end{array}$ & $\begin{array}{l}\text { Rio de Janeiro, other } \\
\text { cities }\end{array}$ & Terra do Meio & Pasture \\
\hline 5 & $\begin{array}{l}\text { Goldminers ("garimpe- } \\
\text { iros") }\end{array}$ & Maranhão & Rondônia, Pará & Mining \\
\hline 6 & Laborers/debt slaves & Maranhão & All ranching areas & Labor for deforestation \\
\hline 7 & Capitalized farmers & $\begin{array}{l}\text { Mato Grosso, Rio } \\
\text { Grande do Sul }\end{array}$ & $\begin{array}{l}\text { Mato Grosso, Santarém, } \\
\text { eastern Rondônia }\end{array}$ & Soybeans \\
\hline 8 & Landgrabbers (“grileiros”) & $\begin{array}{l}\text { Southern, Center- } \\
\text { south, and Center- } \\
\text { west regions }\end{array}$ & $\begin{array}{l}\text { Terra do Meio, Southern } \\
\text { Amazonas, Santarém- } \\
\text { Porto de Moz-Ururuá } \\
\text { triangle }\end{array}$ & Pasture \\
\hline 9 & $\begin{array}{l}\text { Sawmill operators/ } \\
\text { loggers }\end{array}$ & $\begin{array}{l}\text { Espirito Santo, } \\
\text { Paraná }\end{array}$ & $\begin{array}{l}\text { BR-163 Highway, } \\
\text { Tailândia (eastern Pará) }\end{array}$ & $\begin{array}{l}\text { Logging, building access } \\
\text { roads }\end{array}$ \\
\hline
\end{tabular}

were spontaneous squatters ("posseiros") who staked out claims on their own; these individual squatters have since been largely supplanted by organized landless migrants ("sem terras"). Particularly in the case of Rondonia, the result of migration in the 1970s and early 1980s was a great explosion of deforestation. Subsequent population movements to the settlement areas of both Rondônia and the Transamazon Highway were of wealthier farmers who bought one or several of the small farmers' lots in order to establish ranches (Fearnside 1984). Although large properties devote a greater proportion of their land to cattle, pasture is also the dominant land use in small properties (Walker et al. 2000).

Movements within the region now overshadow inter-regional movements as sources of deforestation
(Perz 2002). Such movements are now opening frontiers, with a large role being played by the children of such settlers, such as the migrants from Rondônia who are opening areas in Maputi in southern Amazonas. Within each settlement area, a succession of events takes place in which land use in the area changes (usually to pasture) because of both changes in the land-use behavior of the resident population and replacement of the population by other actors. Individual settlers shift from planting annual crops such as rice to establishing cattle pasture and increasing their herds. At the same time, settlers frequently sell their lots to wealthier newcomers who often consolidate several lots into a small ranch. During the first 5 years of settlement on the Transamazon Highway, the half life of a family in the original colonist population was only 11 years, that is, the attrition rate corresponded to 
Fig. 1. Brazilian Amazonia with locations mentioned in the text.

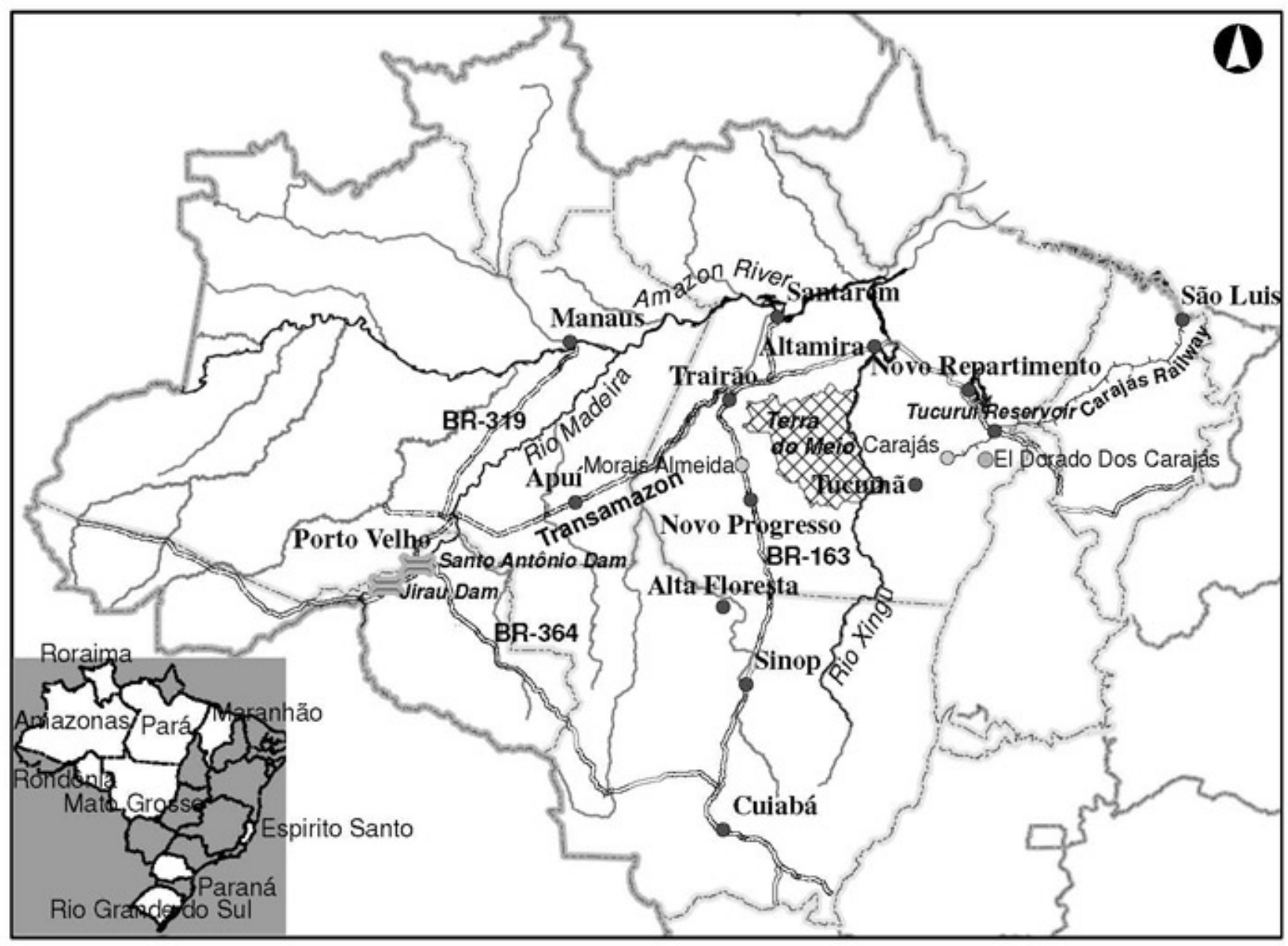

half of the original population departing over this period of time (Fearnside 1986b, page 117).

The small-farmer settlements themselves can be a source of large operators, including "grileiros." In Apuí, in southern Amazonas, the Juma colonization project was established by the National Institute for Colonization and Agrarian Reform (INCRA) in the early 1980 s with settlers primarily coming from the southern Brazilian states of Rio Grande do Sul and Paraná. Today most of the largest landholders in the Apuí area are people who originally arrived as Juma-project colonists (Razera 2005).

Displaced small farmers within the region have become a factor in some locations, such as the large area of deforestation around Novo Repartimento, Pará that was initiated by population moving from the area near the Tucuruí reservoir (Fearnside 1999b). The initial movement into the area in 1992 was to flee from a plague of Mansonia mosquitoes in a settlement area to which they had been assigned on the western shore of the Tucuruí reservoir. The group camped for 2 years at the entry gate to the electrical authority's compound in a vain attempt to get an alternative settlement area. They then followed logging roads that had been built from Tucumã to the Transamazon Highway. By 2003, this area had become one of the fastest growing deforestation hotspots in Amazonia (Fig. 2). 
Fig. 2. Deforestation through 2006 in Brazilian Amazonia. Most of the clearing has taken place in the "arc of deforestation," referring to the crescent-shaped area along the eastern and southern edges of the forest.

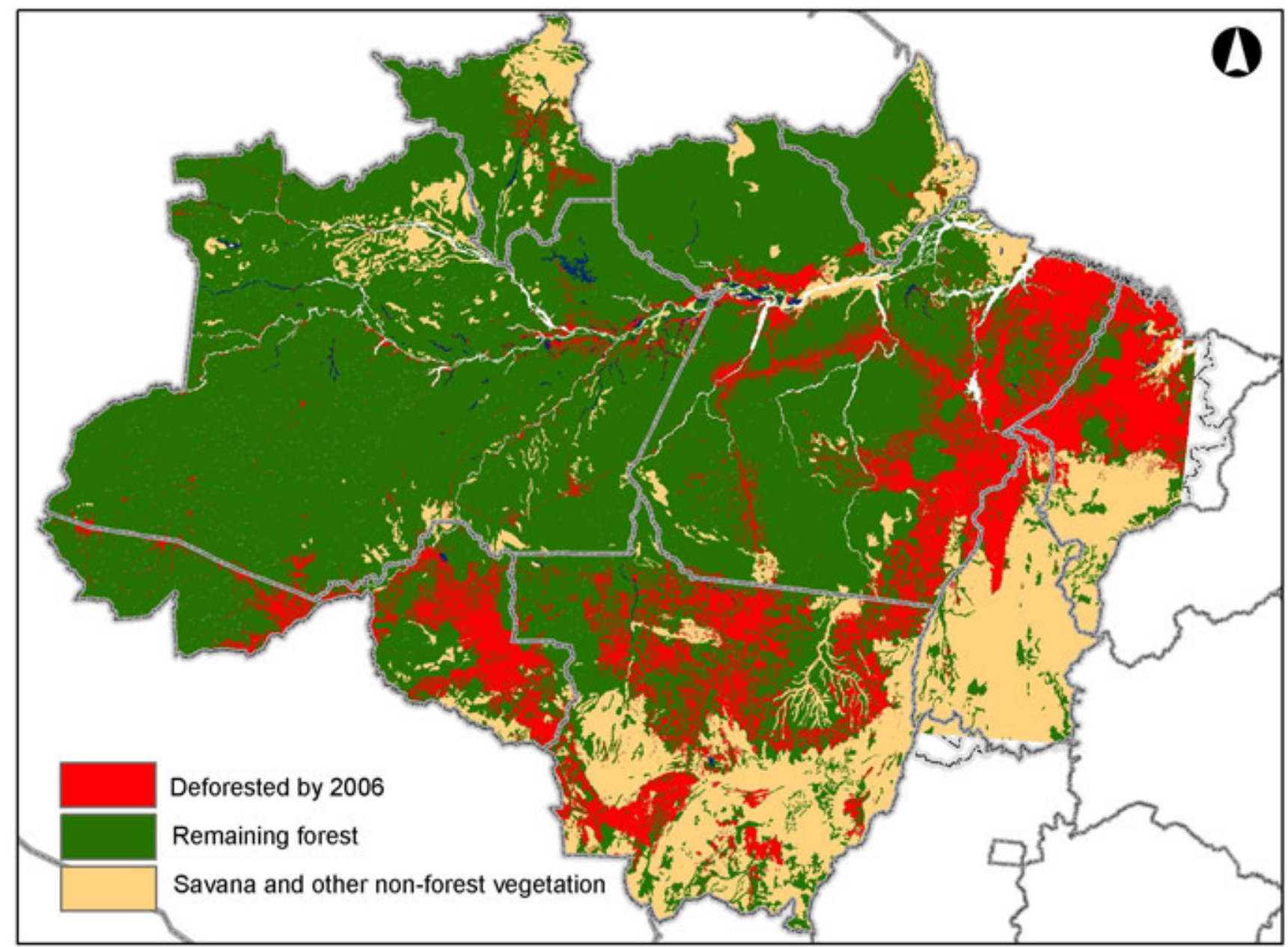

\section{Ranchers}

Ranchers are key actors in Amazonian deforestation and are responsible for most of the clearing. The predominant role of ranchers explains why poverty is not correlated with deforestation in Brazilian Amazonia, unlike many other parts of the tropics (Chomitz 2007, pages 93-98). The profit made by a rancher is the total of the income derived from all sources applicable to a given ranch, not only what comes from the sale of beef cattle. Other sources of income can include sale of timber or logging rights (and, in some locations, charcoal), speculative gains from land sales, government subsidies and the use of the operations in laundering money from crime, corruption, and tax evasion. The relative importance of these "ulterior" income sources, compared with beef sales, varies among locations, among ranchers, and over time. In areas where the initial frontier phase has passed, the "traditional" beef economy is predominant, with land-use decisions being made based on beef production rather than land speculation and other ulterior motives (e.g., Faminow 1998, Margulis 2003, Mattos and Uhl 
1994, Mertens et al. 2002). In limited areas where milk production and processing have become established, particularly in Ouro Preto do Oeste, Rondônia, the profit from this activity is a key driver (Caviglia-Harris 2004, Faminow 1998). The role of beef sales has increased over time with such factors as continual expansion and improvement of the road network, proliferation of slaughterhouses, the opening of export markets (with progress in eliminating foot-and-mouth disease), and in older frontiers, exhaustion of timber and of uncleared land. Ranching for beef or milk production and capitalized farming for soybeans are activities that are especially sensitive to the effect of site quality on expected yield. Expected yield also affects land prices and other drivers. Excessive rainfall in western Amazonas reduces expected yields there, contributing to the persistence of forest (Chomitz and Thomas 2003).

Historically, the importance of ulterior motives for ranching has undergone wide swings. Major booms have passed, such as the incentives from the Superintendency for Development of the Amazon (SUDAM) in the 1970s and early 1980s (Binswanger 1991, Mahar 1979) and generalized land speculation during the hyperinflation before the 1994 Real Plan (e.g., Hecht 1985, Hecht et al. 1988). However, both government subsidies and land speculation continue to play roles in Amazonian ranching.

The importance of beef sales is consistent with the recent history of deforestation rates in Brazilian Amazonia. The price of beef in Brazil in real terms declined steadily from 2001 through early 2006, after which it rose through the end of 2007 (e.g., Kianek 2008). The deforestation rate increased over the 2001-2004 period and then decreased through July 2007, after which it increased again. Beef prices show a strong correlation with the deforestation rate in the following year over the 1995-2007 period (Institute for Man and Environment in the Amazon (IMAZON) unpublished; see Pichonelli and Magalhães 2008). This includes the deforestation peak in 1995 and subsequent decline through 1997, although this fluctuation also derived from the effect of the 1994 Real Plan in releasing investment capital and in stopping inflation and associated land speculation (Fearnside 2005).

The cattle herd in Brazilian Amazonia increased by $173 \%$ between 1990 and 2004 (IMAZON unpublished; see Pichonelli and Magalhães 2008). Brazil's herd as a whole has gone through a major oscillation since 1999, increasing by approximately 20 million head to a peak in 2004 and then declining by an equal amount through 2007, including liquidation of many females. This drawdown, combined with the rising beef prices starting in 2007 , is projected to drive a substantial increase in beef prices through 2009 (Kianek 2008). Beef is a "pernicious" commodity, in contrast to most crops such as soybeans, in that the cattle represent both the product and the means of production. The result is that when prices rise, ranchers hold their stocks (especially females) for reproduction and growth, rather than selling them off (Mascolo 1979). This produces more exaggerated price swings - and a greater stimulus for deforestation. The price of beef can, therefore, be expected to be a powerful driver of Amazonian deforestation by ranchers in the coming years.

\section{Drug Traffickers/Money Launderers}

Significant areas of deforestation can result from use of money from illegal activities elsewhere, for example in areas held by drug traffickers and money launderers in the Terra do Meio between the Xingu River and the BR-163 Highway in Pará (Escada et al. 2005, Geffray 2002, Machado 2002, Pontes Júnior et al. 2004, Schönenberg 2002). The Terra do Meio (Fig. 1) is an area the size of Switzerland that is largely outside of the control of the Brazilian government. Staff from government agencies such as the Brazilian Institute for the Environment and Renewable Natural Resources (IBAMA) only enters the area on brief forays; a plan to establish a base in the area announced in 2003 has still not been carried out. The power of the underground economy to affect deforestation in the Terra do Meio was demonstrated most clearly in 2003 when a 6200-ha clearing appeared in the area in only 3 weeks' time (e.g., Venturieri et al. 2004). The site, known as "the revolver" because of the shape of the clearing, is far from any roads and is in an area that, because of its remoteness, has been calculated to have the lowest farm-gate values of beef cattle in Amazonia (Arima et al. 2005, page 50). The legitimate economy, therefore, cannot explain clearings of this kind. 


\section{Goldminers ("Garimpeiros")}

Mining gold does not directly result in large areas of deforestation, although other environmental and social impacts are severe, including destruction of aquatic habitats, mercury pollution, and negative impact on the health and culture of indigenous peoples. Indirectly, however, gold mining has contributed to deforestation processes. During the 1980s, when the price of gold was at a high point, the prospect of wealth from gold induced thousands of freelance prospectors ("garimpeiros") to come to the Amazon from other parts of Brazil, especially Maranhão. Most of these people remained in the region, usually in some other role such as landless migrants or small farmers. In some cases, money from gold contributed to expanding the agricultural and ranching activities in settlement areas, settlers temporarily leaving their lots to work in the mining areas (MacMillan 1995). In 2008, the crash in financial markets, especially in the United States, suddenly drove gold prices to record levels, raising the prospect of renewed pressure on Amazonia from goldminers.

\section{Laborers/Debt Slaves}

One component of migrants to the region is composed of single men or men who arrive without their families. Many of these people seek employment as laborers, and many find themselves working as slave labor in deforestation crews that are assembled by "gatos" (literally "cats," referring to intermediaries who supply labor to ranchers who contract clearing for an agreed amount per hectare). The laborers buy their food and other supplies on credit from the "gato" at grossly inflated prices and soon accumulate debts that grow faster than any credit can possibly be earned through labor. The result is that the laborer is then trapped as a "slave" who would be shot if he attempted to leave (Rocha 2005). The same applies to the notorious charcoalmaking industry (e.g., Fearnside 1999a, Sutton 1994). Particularly in the case of charcoal making, entire families are held, including children. Both "degrading conditions analogous to slavery" (International Labor Organization 2002) and child labor violate Brazilian labor legislation. Ranchers and intermediaries can "buy" slaves by paying off their debt to another operator (e.g., Agência Carta Maior 2007). Although over the years a minimal enforcement effort has meant that these practices are tolerated in practice on Amazonian deforestation frontiers, there has also been an increased enforcement effort in recent years. In 2002, Brazil had an estimated 15000 such "slaves" (Anonymous 2002), a number that has undoubtedly grown substantially since despite the efforts of a Ministry of Labor "mobile team" to locate and free them. A 2006 estimate placed the number at 25000 just in Pará (Campbell 2006). The presence of slaves contributes to deforestation by providing cheap labor to ranchers and "grileiros." Those laborers who avoid slavery or who are released often become landless migrants, thereby playing other roles in the deforestation process. Between 1995 and 2006, 20 000 slaves were freed in Brazil as a result of government raids, according to the agency responsible (Diário do Pará 2006).

\section{Capitalized Farmers}

More capitalized small farmers come to Amazonia from other regions seeking land purchase, especially those who have sold small farms in southern Brazil and are using the funds to invest in larger parcels in Amazonia. Private settlement projects in Tucumã, Pará and in Alta Floresta, Mato Grosso in the late 1970s and early 1980s facilitated this kind of movement for small landowners from southern Brazil (Browder and Godfrey 1997, pages 226-230). Now this pattern is being followed by soy farmers moving from Mato Grosso to the Santarém area on the BR-163 Highway, and to a lesser degree in the state of Amazonas on the BR-319 Highway. Investment has been increasing in raising beef for export (Arima et al. 2005, Smeraldi and May 2008) and in soybeans (Brown et al. 2005, Fearnside 2001b, Hecht 2005). Soybean plantations are installed both on land converted from pasture and on land converted directly from tropical forest. Land converted from tropical forest is sometimes first planted to another annual crop to "prepare" the soil for soy. In Mato Grosso, deforestation for annual crops is highly correlated to soybean prices in the same year (Morton et al. 2006). Deforestation for both pasture and soybeans increased over the 1997-2004 period, followed by a decline over the 2005-2007 period, coincident with falling international prices for these commodities and a worsening exchange rate of the Brazilian real against the U.S. dollar from the pointof-view of Brazilian exporters (Table 2). The price of soybeans, expressed in reais, declined by half between 2005 and 2007, whereas the deforestation rate fell by a similar percentage between 2004 and 2007 (Arini 2008). 
Table 2. Deforestation in Brazil's Amazonian states

\begin{tabular}{|c|c|c|c|c|c|c|c|c|}
\hline \multirow{3}{*}{ State } & \multirow[b]{3}{*}{ Primary actors } & \multirow{3}{*}{$\begin{array}{r}\text { Original forest } \\
\text { area in } 1500 \\
\left(1000 \mathrm{~km}^{2}\right)\end{array}$} & \multicolumn{2}{|c|}{$\begin{array}{c}\text { Cumulative area } \\
\text { deforested by } \\
2007\end{array}$} & \multicolumn{4}{|c|}{ Deforestation rate $\left(\mathrm{km}^{2} /\right.$ year $)$} \\
\hline & & & $\left(\mathrm{km}^{2}\right)$ & $(\%)$ & 2004 & 2005 & 2006 & 2007 \\
\hline & & & & & & & & \\
\hline Acre & Ranchers & 152 & 19736 & 13.0 & 729 & 539 & 323 & 136 \\
\hline Amazonas & $\begin{array}{r}\text { Ranchers, colo- } \\
\text { nists }\end{array}$ & 1481 & 2104 & 1.8 & 46 & 33 & 30 & 582 \\
\hline Amapá & $\begin{array}{l}\text { Ranchers, colo- } \\
\text { nists }\end{array}$ & 115 & 36749 & 2.5 & 1211 & 752 & 780 & 0 \\
\hline Maranhão & $\begin{array}{l}\text { Ranchers, Capi- } \\
\text { talized farmers, } \\
\text { colonists }\end{array}$ & 143 & 110180 & 77.0 & 755 & 922 & 651 & 631 \\
\hline Mato Grosso & $\begin{array}{l}\text { Ranchers, Capi- } \\
\text { talized farmers }\end{array}$ & 528 & 195698 & 37.1 & 11814 & 7,145 & 4333 & 2476 \\
\hline Pará & $\begin{array}{l}\text { Ranchers, Land- } \\
\text { grabbers, Sawmill } \\
\text { owners, Landless } \\
\text { migrants, Colo- } \\
\text { nists }\end{array}$ & 1139 & 245001 & 21.5 & 8521 & 5731 & 5505 & 5569 \\
\hline Rondônia & $\begin{array}{r}\text { Colonists, Ranc- } \\
\text { hers, Capitalized } \\
\text { farmers }\end{array}$ & 215 & 78097 & 36.3 & 3834 & 3233 & 2062 & 1465 \\
\hline Roraima & $\begin{array}{r}\text { Ranchers, Colo- } \\
\text { nists }\end{array}$ & 164 & 8235 & 5.0 & 311 & 133 & 231 & 306 \\
\hline Tocantins & $\begin{array}{l}\text { Ranchers, Capi- } \\
\text { talized farmers }\end{array}$ & 59 & 28011 & 47.6 & 158 & 271 & 124 & 59 \\
\hline Legal Amazon & & 3996 & 723813 & 18.1 & 27379 & 18759 & 14039 & 11224 \\
\hline
\end{tabular}

A recovery of soy prices in 2007 has spurred a surge of deforestation activity in the state of Mato Grosso. Internationally, the price of soybeans rose throughout 2007, entering into the territory of alltime record prices on the Chicago Commodity Exchange beginning in December 2007 (Globo Video 2008). Between August and November 2007, approximately $7000 \mathrm{~km}^{2}$ were deforested according to an estimate based on MODIS satellite data released by the Instituto Nacional de Pesquisas Espaciais (INPE) (Brazil, INPE 2008). The Minister of Agriculture (Reinhold Stephanes) and the governor of Mato Grosso (soybean magnate Blairo Maggi) vigorously denied any connection between soybeans and the deforestation surge (Sant'Anna 2008). However, although many of the 36 municipalities identified as deforestation hotspots are located in areas dominated by ranching, several 
are right in the middle of the soy belt in Mato Grosso, such as Nova Ubiratã, Ulianópolis, and Querência (Zanini and Cabral 2008).

The current rush to biofuels represents an additional future attraction for movement of capital and capitalized farmers to Amazonia (Kileen 2007). In 2007, the Brazilian government began an intensive campaign to attract international interest in importing biofuels from Brazil, particularly alcohol from sugarcane. The Ministry of External Relations repeatedly claimed that there is "no limit" to how much biofuel Brazil can export-whatever the world wants to buy, Brazil can expand its production to supply it. Unfortunately, Brazil, like every other country, does have limits. In this case, severe limits are implied by the environmental impact of greatly expanding areas of crops for feedstocks. Energy crops destroy natural ecosystems both by replacing them directly and by displacing other land uses, especially cattle pasture, to forest areas in Amazonia. Cattle have been displaced to Amazonia from former ranching areas in other parts of Brazil by the advance of soybeans and, more recently, sugarcane for alcohol (Smeraldi and May 2008). Recent analyses have shown that the net result of converting tropical forest to energy crops is highly negative for many decades (Fargione et al. 2008, Searchinger et al. 2008a). In fact, the impact of current trends is even more negative because these analyses do not include the additional impact of deforestation for cattle ranching that is displaced into Amazonia by expansion of energy crops in other parts of Brazil (Searchinger et al. 2008b, page $11)$.

\section{Landgrabbers (“Grileiros”)}

A form of movement with significant consequences is represented by groups of large illegal landgrabbers ("grileiros"). "Grilo" means "cricket" in Portuguese, and the term "grileiro" is supposedly a reference to a practice (whether it be fact or lore) of forged titles being made to look old by placing them for a few days in a box filled with crickets. "Grileiros" obtain large blocks of land through forgery, bribery, and/or violence. These practices are made easier by the confused and overlapping land claims in Amazonia and by the decentralized nature of "cartorios" (document repositories) scattered across the region in municipal seats. "Grileiros" can make money by exploiting timber and other resources whether or not they are ultimately successful in obtaining title. They make large profits by subdividing and selling their claim to others, who may or may not be aware of the illegal status of the land claim. Holding claims requires the services of gunslingers ("pistoleiros") and others on the ground in the areas involved. Movement of "grileiros" from the BR-163 Highway in Pará to the Apuí area in Amazonas is a type of event that can result in large areas of deforestation even though the number of people is small (Fearnside 2007).

\section{Sawmill Operators/Loggers}

Sawmill owners represent another migratory group with great impact on the forest. A substantial number came to Amazonia after destroying the Atlantic forest in either Espirito Santo or Paraná. These groups first came to areas in northern Mato Grosso such as Sinop, but with exhaustion of the forest have moved on to Rondônia or to areas on the BR-163 Highway such as Moraes de Almeida and Novo Progresso (e.g., Schneider et al. 2000, Alencar et al. 2004, Lentini et al. 2005).

Each year, logging affects an area approximately as large as the areas being deforested. Asner et al. (2005) used LANDSAT imagery to estimate an average of $15383 \mathrm{~km}^{2} /$ year over the 2000-2002 period, excluding the state of Amazonas. Brazil's National Communication to the climate convention reports a rate an order of magnitude lower (Brazil, Ministry of Science and Technology (MCT) 2004, page 150), but this estimate appears to have detected only the logging decks (small clearings where logs are piled before transport) rather than the forest from which $\operatorname{logs}$ have been removed. The impact of logging is greatly magnified because of the increased probability of forest fires entering the logged areas, thereby setting in motion a positive feedback process that degrades the forest by successively more severe fires (Cochrane 2003, Cochrane et al. 1999).

\section{FUTURE MOVEMENTS OF ACTORS}

In the future, major movements are expected as a result of two planned dams on the Madeira River, scheduled for completion in 2012. The dams will employ 20000 construction workers and this contingent of unemployed men will be dumped almost simultaneously on Porto Velho at the end of the construction phase. The planned reconstruction 
of the BR-319 Highway from Porto Velho to Manaus makes it likely that a significant movement will occur to central Amazonia and to Roraima, opening new frontiers to deforestation (Fearnside and Graça 2006).

The plans for hydroelectric dam construction have tremendous potential to stimulate migration. The only time the full extent of dam-building plans has been released was the 2010 Plan in December 1987 (Brazil, Eletrobrás 1987; see Fearnside 1995). The plan listed 79 dams in Brazil's 5 million $\mathrm{km}^{2}$ Legal Amazon region, flooding $100000 \mathrm{~km}^{2}$ or $2 \%$ of the region. Many of these dams would displace significant resident populations, and all would stimulate migration through the temporary employment offered during the construction phase and by the roads built to each dam site (e.g., Fearnside 2001c, 2006).

\section{TRANSFORMATIONS OF LAND AND ACTORS}

The nine categories of actors discussed above, and the locations they occupy, can undergo a series of transformations over time. The land in a particular place may start as public land and be invaded either by large "grileiros," by individual squatters, or by "sem terras" (Fig. 3). Ranchers may purchase large blocks of land from "grileiros" or may buy a number of small colonist lots. The ranches can be invaded by squatters or "sem terras," or, if the land is economically attractive for soybeans, the properties can be sold to capitalized farmers.

Money flows from external sources to specific groups of actors and speeds their clearing (Fig. 4). Money from illegal sources can be laundered through investments by "grileiros" and speculators, ranchers, and loggers. Government subsidies make important contributions to ranchers, colonists, capitalized farmers and, strange as it may seem, to "sem terras" (see Fearnside 2001a). External legal sources flow mainly to ranchers and capitalized farmers. Loggers play an important role by providing a source of funds through timber sales by other actors, such as "grileiros," ranchers, colonists, and "sem terras."

The actors themselves can pass from one category to another with time, whether they remain in the same location or not (Fig. 5). Those who come to Amazonia from other regions can be grouped into "poor" and "non-poor" categories. Poor migrants have options as laborers (often as "slaves"), as goldminers, as squatters, and as "sem terras," or as urban residents. Those who become goldminers or slaves may later enter the ranks of squatters and "sem terras." "Sem terras" may be offered legal lots as colonists or may migrate to "favelas" (shanty towns) in urban areas. Colonists may leave for urban areas or may expand their holdings to become middle-sized ranchers, and some of these will expand to become large ranchers. Urban centers drain some of the population from groups such as "sem terras," colonists, and middle-sized ranchers.

\section{POLICY IMPLICATIONS}

Given the actors and processes discussed above, measures that need to be taken to reduce deforestation can be grouped into the following categories:

\section{Remove Motives for Deforestation}

\section{Stop regularizing land claims}

The violence and lawlessness of the Amazon frontier is often compared with that of the "wild west" of $19^{\text {th }}$-century North America. The parallel with changes that took place in North America is relevant, although greater expectation of government support for smallholders in Brazil led to significantly more violent conflict (Alston et al. 1998). The "closing of the frontier" in the United States in 1890 (Turner 1893) marked a turning point after which land for the taking was no longer available. Since that time, it has been the general assumption that anyone who is poor or unemployed must search for some sort of employment, either in the urban or rural setting. The possibility of simply entering an area of forest and clearing a homestead never even crosses people's minds, and were such a thing to happen, the squatter would be removed by police.

The movement of population and investment in Amazonia (and its associated deforestation) are, in large part, based on the expectation that invading and claiming public land will eventually be rewarded by a permanent land title. This has been the pattern in Brazil for over 400 years and is only likely to change by either reaching the end of the 
Fig. 3. Land holdings: transformations in the status of a given piece of land over time.

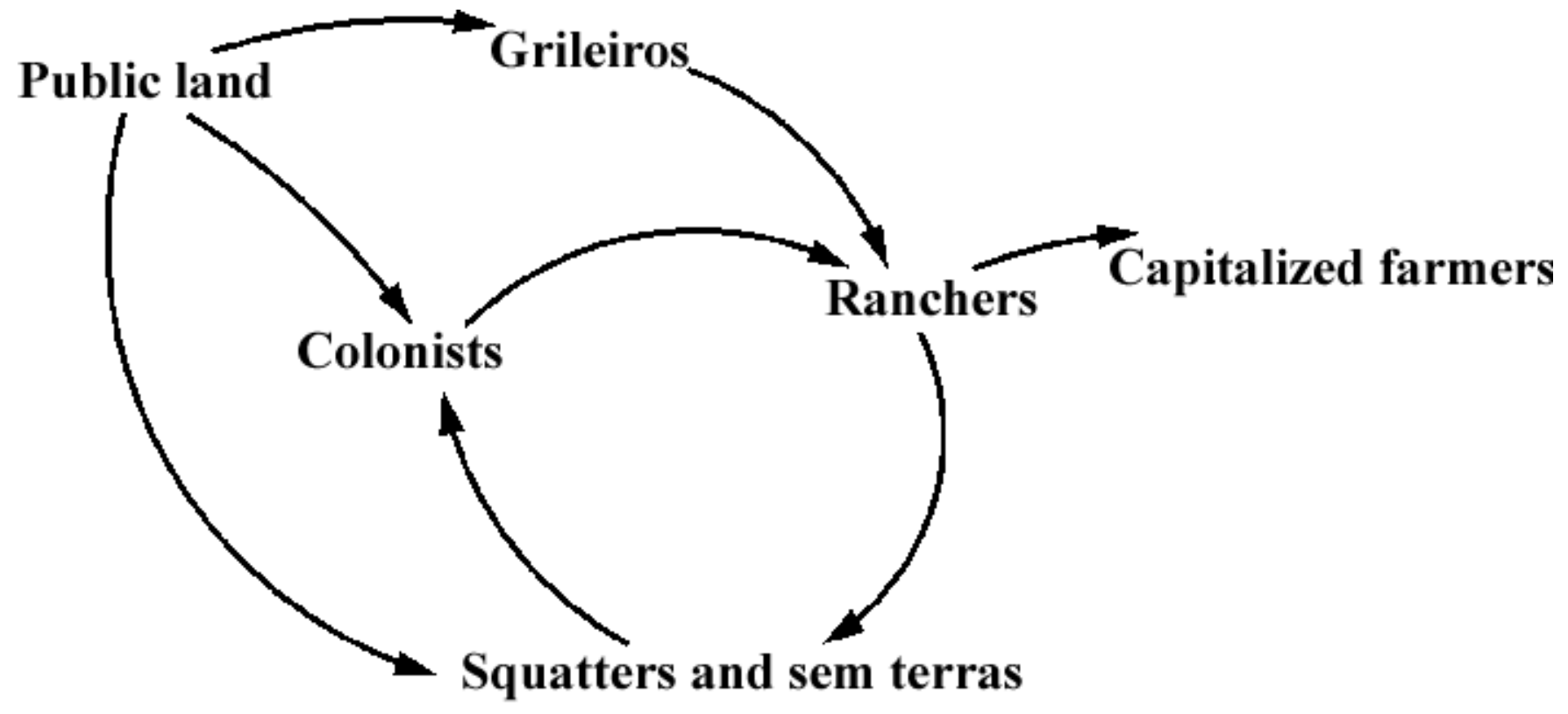

available land or by an alteration of national policy that is sufficiently visible and consistently enforced to be accepted by the population (Fearnside 1979). Estimates of the number of landless families in Brazil range from 5 to 10 million, which means that even if the entire Amazon region were distributed as 50-ha lots, it would be insufficient to solve the landlessness problem (e.g., Fearnside 1985). Taking concrete steps to bring about the transition to end "regularization" of land claims in Brazil is the most basic priority if the damage from movement of population and investment is to be contained. Of course, this transition cannot take place in isolation from programs to offer alternative livelihoods to the population. Nonetheless, the bottom line is that the frontier must be unambiguously closed.

\section{Cut subsidies}

A variety of subsidies encourage loggers, ranchers, and others. The effect of subsidies has evolved over time, but, contrary to popular perception, they are important drivers of deforestation to this day. In the 1970s and early 1980s, subsidies through the Superintendency for the Development of Amazonia (SUDAM) provided vast sums to large cattle ranches, both through generous financing at interest rates below the prevailing rate of inflation and through credit against taxes owed on unrelated operations elsewhere in the country, in addition to tax exemptions on the ranching operations themselves (e.g., Fearnside 1987, Mahar 1979). These programs dwindled in the mid 1980s, but did not actually end until the mid 1990s, years after official pronouncements had repeatedly claimed they no longer existed. In fact, the tax exemptions on the original SUDAM-approved ranches persist to this day (Brazil, Receita Federal 2007).

Other subsidy programs have been added since the heyday of the SUDAM ranches. The Constitutional Fund of the North (FNO) distributes funds from the Banco da Amazônia (BASA). Under this is the National Program for Strengthening Family Agriculture (Pronaf), which was created in 1995 and expanded under the current presidential administration beginning in 2003. A study by IMAZON has shown that Pronaf financing for small farmers in official settlement areas results in much higher deforestation rates than for comparable farmers in areas outside of the official settlements, because farms outside the settlements lack access to the subsidized credit program (Domingos 2008). Interest rates for small farmers are far lower than 
Fig. 4. Money flows: major financial flows to and among actors.

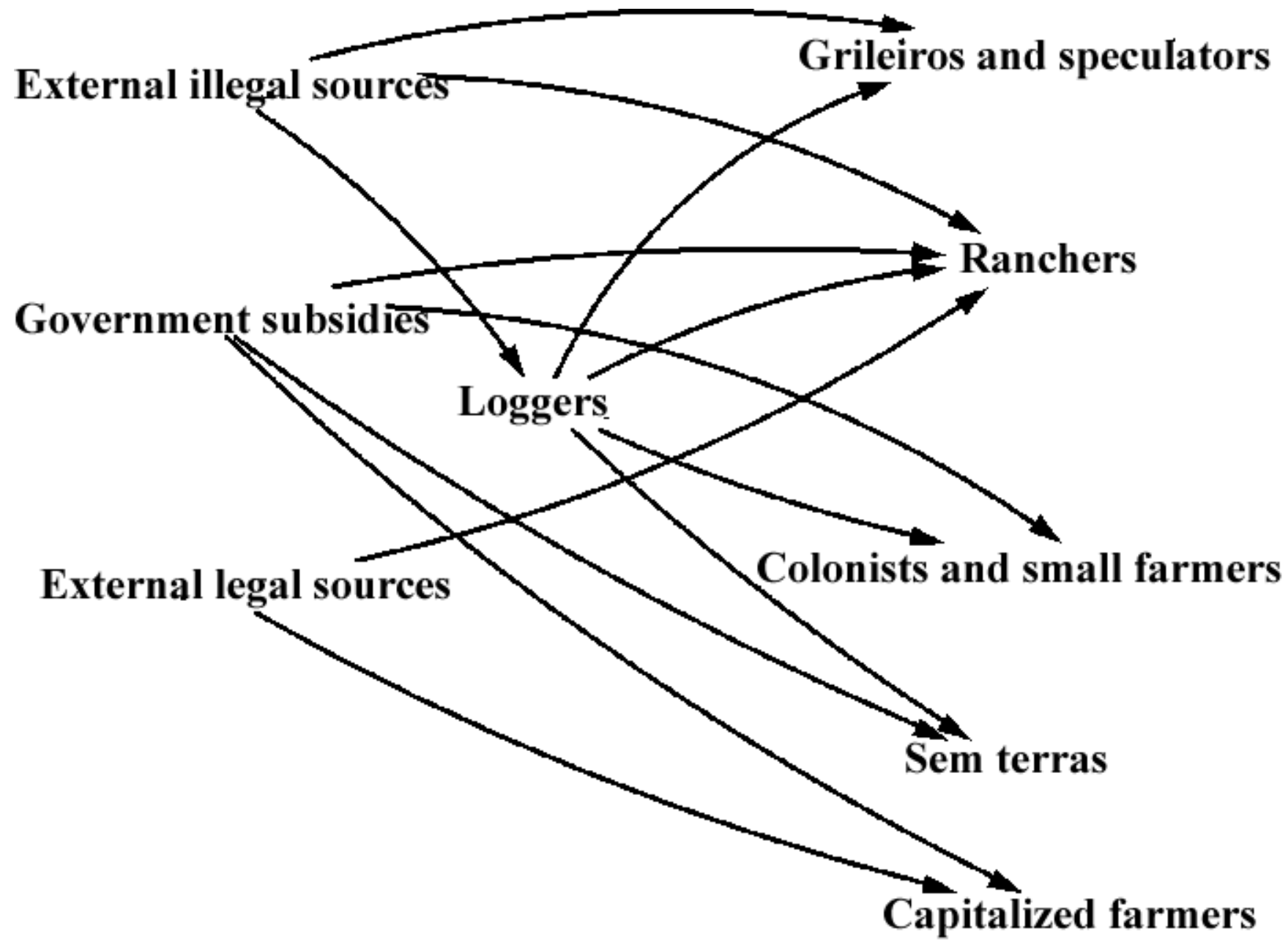

those for any other enterprise at 1\%-4\% annually, compared with the standard rate from Brazil's Central Bank of $11.25 \%$. In addition, small farmers get a discount of $25 \%$ if they repay the loan on time, plus a further "bonus" discount of $40 \%$ for loans under R\$12 000 (approximately US\$6700) (Domingos 2008). BASA also lends FNO funds to medium and large property owners at subsidized rates: 5\%-9\% annual interest depending on the size of the property, plus a $15 \%$ discount for payments made on time (Domingos 2008). Aside from the subsidized interest and the effects of discounts, these loan programs in practice have a large additional subsidy because of the chronic practice of forgiving unpaid debts as part of "amnesty" programs when weather or other conditions result in large losses (see Fearnside 2001a). In addition to Brazilian government subsidies, international funds have similar effects. Particularly controversial was a second loan from the World Bank Group's International Finance Corporation (IFC) in 2004 to the André Maggi Group for soybeans in Mato Grosso (e.g., Stickler et al. 2005). The loan was classified as "Category B" by the IFC, meaning that it was not expected to result in environmental impact and was exempted from environmental review procedures within the Bank. The IFC's own auditing concluded that the "Category B" classification was unwarranted and recommended measures to avoid similar errors (IFC, CAO 2005). However, in 2007, 
Fig. 5. Population: transformations over time of a given individual or family.

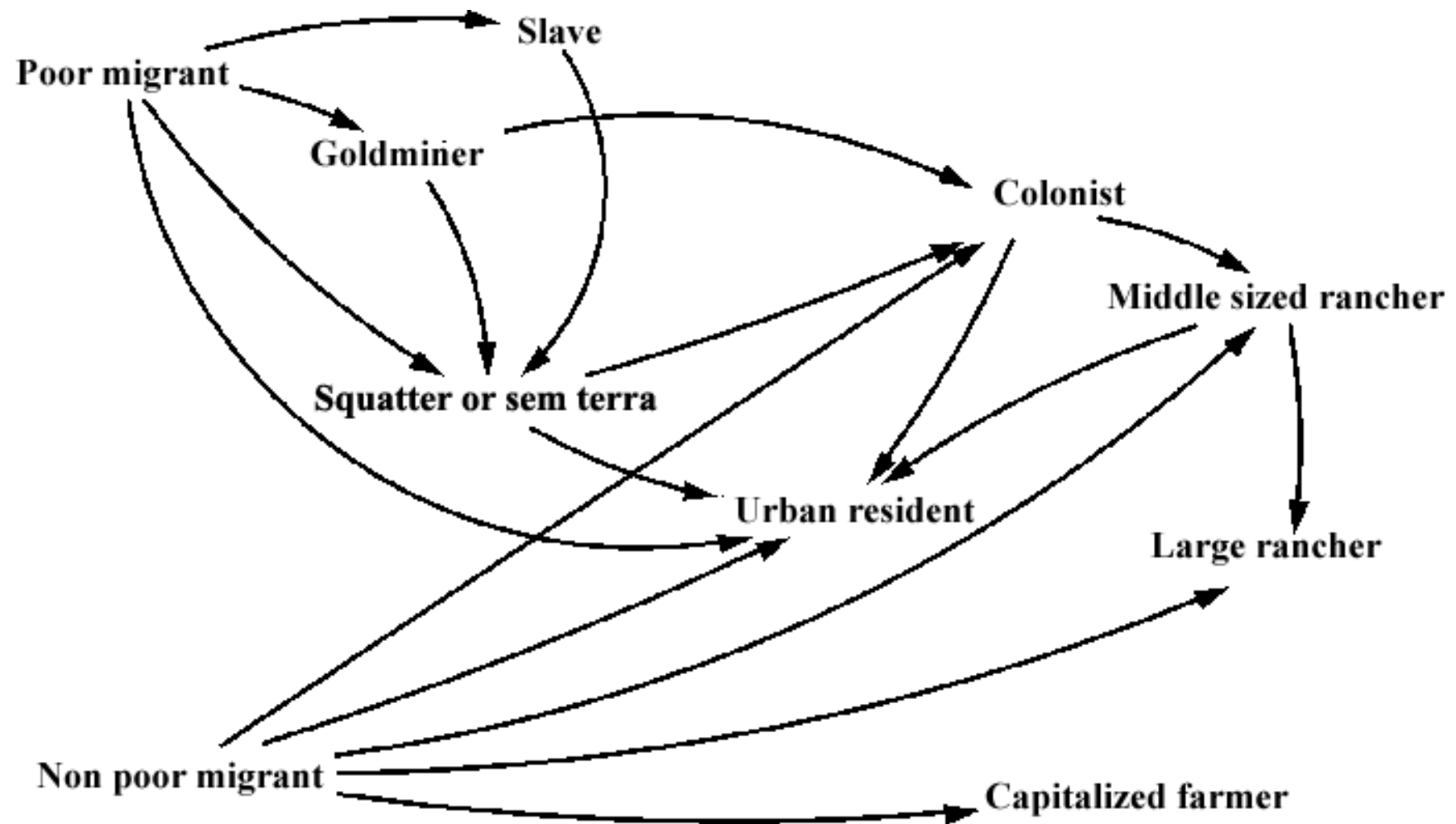

the IFC granted a major loan to the Bertin Group for slaughterhouses in Pará under almost identical circumstances (Folha de São Paulo (FSP) 2007). All of these subsidies need to be ended.

\section{Establish the Rule of Law}

\section{Complete a cadaster of land titles}

Associating clearings observed from satellites with specific landowners requires a cadaster, or register, of properties with georeferenced boundaries. Such a cadaster has long been an official goal of INCRA, but successive delays and budget cuts have prevented reaching the goal anywhere in the region. The decentralized system of document depositories ("cartorios") in Brazil is particularly susceptible to corruption and to maintenance of conflicting, overlapping, and incompletely described landholdings. The surge in deforestation in late 2007 provoked an announcement that the cadaster will be completed first for properties $>250$ ha in area in the 36 municipalities that accounted for most of the clearing surge (Brazil, INCRA 2008).

\section{Reinforce command and control}

Command-and-control operations can restrain deforestation through licensing and repression. Skepticism regarding the government's ability to control deforestation is frequent due to the long history of "packages" of government measures being announced whenever satellite data are released indicating an increase in deforestation, after which the deforestation rate may increase or not with no perceptible effect resulting from the repression program. This skepticism among Brazilian negotiators of agreements under the UN Framework Convention on Climate Change has been at the root of the country's traditional refusal to consider carbon credit for avoided deforestation, the fear being that if Brazil commits itself to reducing deforestation by a specific amount and 
then fails to do so, the country could be subject to pressures that would jeopardize its sovereignty over Amazonia (see Fearnside 2001d, Fearnside and Barbosa 2003). The example of the Mato Grosso state government's deforestation and licensing program from 1999 to 2001, when a measurable reduction in deforestation could be attributed to the program, serves as an important example for this reason (Fearnside 2003).

Illegal logging has proved to be more difficult to control than deforestation. This situation may improve in the future due to recent advances in satellite detection of logging disturbance (Asner et al. 2006), plus administrative advances in replacing easily forged or corrupted documentation. Nevertheless, the high monetary value and the ephemeral nature of logging activity make control measures inherently easy to corrupt. Certification of "sustainable" forest management operations has potential, but these operations cannot be economically competitive unless illegal "predatory" logging can be stopped. In 1997, Brazil's Secretariat of Strategic Affairs estimated that $80 \%$ of logging in Brazilian Amazonia was illegal (Brazil, Secretaria de Assuntos Estratégicas (SAE) 1997, cited by Greenpeace 2001). Subsequently, a series of provisions made it easier to "legalize" the extracted timber, such that an estimated $75 \%$ of the timber had some sort of documentation by 2002, but virtually all of this wood remained just as predatory in its origins (John 2002).

\section{Discourage Movement to Frontier}

\section{Exercise restraint in approving infrastructure}

Restraint must be exercised in approving and building infrastructure that has a high potential to spread deforestation (Fearnside 2002, Laurance et al. 2001). Roads are the principal factor leading to movement of population and to increased land prices and consequent land speculation (in addition to increased agricultural profitability). Economic analyses indicate that decreasing the transport costs from Amazonia to the rest of Brazil is one of the factors that has the greatest effect on increasing deforestation (Cattaneo 2001). Since 1986, an Environmental Impact Study (EIA) and associated Report on Impact on the Environment (RIMA), jointly known as the "EIA/RIMA," have been required for infrastructure projects, despite a variety of cases where project proponents have managed to circumvent the requirement. The EIA/RIMA has a potentially important role to play in restraining the construction of particularly damaging infrastructure projects. However, the EIA/RIMA has so far been restricted to legitimizing decisions on infrastructure that have, in fact, been made before the studies are undertaken. In addition, the EIA/RIMA restricts itself to direct effects, such as the roadbed of a highway, rather than the much more important effects of deforestation stimulated by the road in the surrounding area (e.g., Fearnside 2007). The system of contracting the studies by project proponents also involves obvious biases in favor of whatever project is proposed (e.g., Fearnside and Barbosa 1996). The system must be strengthened such that the full impact of the proposed projects is assessed and compared with other alternatives (including noproject alternatives) before decisions are made.

\section{Create and protect conservation units}

Protected areas, including indigenous areas, have a significant effect on deforestation (e.g., Schwartzman et al. 2000, Ferreira et al. 2005, Nepstad et al. 2006). This last category, which has so far been the most widely applied, is currently under threat from a proposed law in the National Congress that would remove authority from the Ministry of the Environment and from the President to create new protected areas, and require approval by the National Congress for any new reserves. This proposal of the "Ruralist block" (a voting block of representatives of large landholders) would effectively end any further expansion of Brazil's protected-areas network.

\section{Create Economic Alternative}

\section{Create employment in source areas and alternative destinations}

Employment opportunities are needed for potential migrants in source areas and in alternative destinations, including urban centers. This is important for poor migrants, such as those coming from Maranhão. It should not be confused with facilitating the investments of wealthy entrepreneurs (Fearnside 1989b). It is important to remember also that, although alternatives in source areas (including agrarian reform) are important and deserve continual government support, ending the regularization of invasions by landless migrants in Amazonia cannot be held hostage to eliminating poverty in the rest of Brazil. 


\section{Support sustainable uses}

Maintaining population in the forest requires implantation and regulation of sustainable uses of standing tropical forest, including "extractivism" of non-timber forest products such as rubber and Brazil nuts, and forest management for timber. Certification efforts are an important part of these efforts.

\section{Support alternative supply of domestic markets}

National markets for food and fiber must have sources of supply that do not require cutting Amazonian forest. Wood in particular must eventually be supplied from plantations for all uses that do not require particular species from native forest (i.e., musical instruments, etc.). Of all of the countries in the world, Brazil consumes the largest amount of tropical forest wood, totaling 34 million $\mathrm{m}^{3}$ of logs in 1997 (Smeraldi and Veríssimo 1999). Only $5 \%$ of the harvested tropical forest wood is exported, the rest being used domestically (Smeraldi and Veríssimo 1999). Brazil's large areas of silvicultural plantations are used almost exclusively for pulp and charcoal, not for solid wood (Fearnside 1998). A transition to plantation sources will require closing off the supply of cheap timber from Amazonian forests.

The distinction between national and international markets is essential. The Brazilian government has a certain responsibility to supply the country's population with products such as food, wood, electricity, and minerals. However, Brazil has no obligation to supply these products to any other country. Whether Brazil exports products with environmental impacts represents a national decision in which the country is free to pick and choose among various possible export products based on its own interests. Products with strong environmental impacts include tropical timber, aluminum (which motivates much of Brazil's rush to build hydroelectric dams), and potentially biofuels. Brazil and Amazonia are not a vast storehouse from which the world is free to obtain whatever it might want to buy (e.g., Fearnside 1989c, 2006). A decision of this type has been taken in the case of mahogany (Swietenia macrophylla), for which a harvesting moratorium is in effect in recognition of the environmental damage that exploiting this species inflicts on the forest. Countries that want to buy mahogany can obtain it in Bolivia or elsewhere, but not legally from Brazil.
The same principle could be applied to a variety of other highly damaging products.

\section{Reward environmental services}

The environmental services of the forest include avoiding global warming, maintaining the hydrological cycle, and maintaining biodiversity. These have much greater value to society than does what is obtained by destroying the forest to sell timber, plant cattle pasture, etc. Creating institutional mechanisms to translate this value into monetary flows that sustain both the region's rural population and the forest is the primary challenge facing efforts to create an alternative economy of the magnitude needed (Fearnside 1997). Although continuous progress has been made in the over two decades since this author proposed such a transition, the forces driving forest destruction have advanced tremendously. Examples of schemes for direct payments for environmental services to private landholders in tropical countries outside of Amazonia illustrate the difficulties involved in balancing social and environmental goals (e.g., Grieg-Gran et al. 2005, Karousakis 2007, SánchezAzofeifa et al. 2007). An incipient initiative in Brazil's state of Amazonas (Viana and Campos 2007) needs to be carefully watched to ensure that its carbon benefits are real and that a variety of potential negative side effects are avoided (Fearnside 2008). It is essential that such limited payment for environmental services programs functions properly as a prelude to larger monetary flows that could be generated through international negotiations such as those under the UN Framework Convention on Climate Change (UNFCCC). The UNFCCC has progressed the furthest toward rewarding environmental services, in this case the carbon storage functions of the forest, but other environmental services are equally valuable and must eventually be rewarded.

\section{CONCLUSIONS}

The impact on deforestation of actors and their movements in Brazilian Amazonia depends greatly on the actors involved. Cattle ranching predominates in deforested areas, allowing a small human population to have a large impact on clearing. The effects are large and rapid when movements are of actors such as "grileiros," sawmill owners, and ranchers with illicit income sources. Other actors include capitalized farmers who invest 
in legitimate agriculture, and a number of types of poor migrants, including goldminers, laborers, colonists, and squatters. Limiting deforestation will require measures that affect all of these diverse groups.

Removing the motives for deforestation will require a stop to regularizing land claims, as well as cutting the various subsidies through which Brazilian taxpayers still contribute to the profitability of clearing. Controlling deforestation requires establishment of the rule of law throughout Amazonia, including a complete cadaster, or register, of land titles and reinforcement of command-and-control programs. Movement to the frontier must be discouraged by exercising restraint in approving infrastructure projects, especially for highways, and by creating and protecting conservation units. At the same time, economic alternatives must be created by generating employment in source areas and in alternative destinations, by supporting sustainable uses of the forest and alternative supply of national markets for products such as wood. Most fundamental is continued progress in creating mechanisms to reward the environmental services of standing forest as an alternative foundation for the economy in rural Amazonia.

Responses to this article can be read online at: http://www.ecologyandsociety.org/voll3/iss1/art23/responses/

\section{Acknowledgments:}

Paper presented at the Symposium on "The influence of human demography and agriculture on natural systems in the Neotropics, "Association for Tropical Biology and Conservation 2007 Annual Meeting, Morelia, Michoacán, Mexico, 15-19 July 2007, with travel funding from NSF (DEB-0731594). The Conselho Nacional do Desenvolvimento Científico e Tecnológico (CNPq: Proc. 306031/2004-3, 474548/2006-6, 557152/2005-4, 420199/2005-5), Rede GEOMA, and the Instituto Nacional de Pesquisas da Amazônia (INPA: PPI PRJ05.57) contributed financial support. E. H. Keizer produced the figures. M. Aide, R. Grau, $L$. Gunderson, and three anonymous reviewers made valuable comments on the manuscript.

\section{LITERATURE CITED}

Agência Carta Maior. 2007. MPF denuncia esquema de "venda" de escravos no Pará. Agência Carta Maior, 13 January 2007. [online] URL: http:/ /www.amazonia.org.br/noticias/noticia.cfm?id=230489

Alencar, A., D. C. Nepstad, D. McGrath, P. Moutinho, P. Pacheco, M. del C. V. Diaz, and B. Soares-Filho. 2004. Desmatamento na Amazônia: indo além da emergência crônica. Instituto de Pesquisa Ambiental da Amazônia (IPAM), Belém, Pará, Brazil.

Alston, L. J., G. D. Libecap, and B. Mueller. 1998. Property rights and land conflict: a comparison of settlement of the U.S. western and Brazilian Amazon frontiers. Pages 55-84 in J. H. Coatsworth and A. M. Taylor, editors. Latin America and the world economy since 1800. Harvard University Press, Cambridge, Massachusetts, USA.

Anonymous. 2002. Brasil tem 15 mil trabalhadores escravos, diz pesquisa. O Estado de São Paulo, 24 October 2002. [online] URL: http://www.estadao.c om.br/arquivo/nacional/2002/not20021024p54089. $\underline{\text { htm. }}$.

Arima, E., P. Barreto, and M. Brito. 2005. Pecuária na Amazônia: tendências e implicações para a conservação ambiental. Instituto do Homem e Meio Ambiente da Amazônia (IMAZON), Belém, Pará, Brazil.

Arini, J. 2008. A volta das derrubadas. Época, 28 January 2008, page 59.

Asner, G. P., E. N. Broadbent, P. J. C. Oliveira, M. Keller, D. E. Knapp, and J. N. M. Silva. 2006. Condition and fate of logged forests in the Brazilian Amazon. Proceedings of the National Academy of Sciences 103:1297-12950.

Asner, G. P., D. E. Knapp, E. N. Broadbent, P. J. C. Oliveira, M. Keller, and J. N. Silva. 2005. Selective logging in the Brazilian Amazon. Science 310:480-482.

Binswanger, H. P. 1991. Brazilian policies that encourage deforestation in the Amazon. World Development 19:821-829.

Brazil, Eletrobrás. 1987. Plano 2010: relatório 
geral, plano nacional de energia elétrica 1987/2010 (Dezembro de 1987). Centrais Elétricas Brasileiras (ELETROBRáS), Rio de Janeiro, RJ, Brazil.

Brazil, INCRA. 2008. MDA e INCRA anunciam como será o recadastramento de imóveis rurais na Amazônia-20/02/2008. Instituto Nacional de Colonização e Reforma Agrária (INCRA), Brasília, DF, Brazil [online] URL: http://www.amazonia.org. br/noticias/noticia.cfm?id=262079.

Brazil, INPE. 2008. INPE estima que Amazônia perdeu cerca de $7 \mathrm{mil} \mathrm{km} \mathrm{km}^{2}$ de floresta entre agosto e dezembro de 2007. Instituto Nacional de Pesquisas Espaciais (INPE), 24 January 2008, São José dos Campos, SP, Brazil. [online] URL: http://www.am azonia.org.br/noticias/noticia.cfm?id=260154.

Brazil, Ministry of Science and Technology (MCT). 2004. Brazil's National Communication to the United Nations Framework Convention on Climate Change. General Coordination on Global Climate Change, Ministry of Science and Technology (MCT), Brasília, DF, Brazil.

Brazil, Receita Federal. 2007. Perguntas $e$ respostas: pessoa juridica. Ministério da Fazenda (MF), Brasilia, DF, Brazil. [online] URL: http://ww w.receita.fazenda.gov.br/Publico/Perguntao/DIPJ2007/ PergRespDIPJ2007.pdf.

Brazil, Secretaria de Assuntos Estratégicas (SAE). 1997. Política florestal: exploração Madeireira na Amazônia. Secretaria de Assuntos Estratégicas (SAE), Brasília, DF, Brazil.

Browder, J. O., and B. J. Godfrey. 1997. Rainforest cities: urbanization, development and globalization of the Brazilian Amazon. Columbia University Press, New York, New York, USA.

Brown, J. C., M. Koeppe, B. Coles, and K. P. Price. 2005. Soybean production and conservation of tropical forest in the Brazilian Amazon: the case of Vilhena, Rondônia. Ambio 34:462-469.

Campbell, U. 2006. Senzalas na Amazônia. Correio Braziliense, 2 May 2006. [online] URL: http://www.amazonia.org.br/noticias/noticia.cfm? $\underline{\mathrm{id}=206947 .}$.

Cattaneo, A. 2001. Deforestation in the Brazilian Amazon: comparing the impacts of macroeconomic shocks, land tenure, and technological change. Land Economics 77:219-240.
Caviglia-Harris, J. L. 2004 . Household production and forest clearing: the role of farming in the development of the Amazon. Environment and Development Economics 9:181-202.

Chomitz, K. M. 2007. At loggerheads?: agricultural expansion, poverty reduction, and environment in the tropical forests. World Bank, Washington, D.C., USA. [online] URL: http://go.w orldbank.org/155PA8IUZ0.

Chomitz, K. M., and T. S. Thomas. 2003. Determinants of land use in Amazônia: a fine-scale spatial analysis. American Journal of Agricultural Economics 85:1016-1028.

Cochrane, M. A. 2003. Fire science for rainforests. Nature 421:913-919.

Cochrane M. A., A. Alencar, M. D. Schulze, C. M. Souza, Jr., D. C. Nepstad, P. Lefebvre, and E. A. Davidson. 1999. Positive feedbacks in the fire dynamic of closed canopy tropical forests. Science 284:1832-1835.

Diário do Pará. 2006. Pará continua no topo do trabalho escravo. Diário do Pará, 23 April 2006. [online] URL: http://www.amazonia.org.br/noticias/ noticia.cfm?id=206158.

Domingos, J. 2008. Crédito fácil do governo contribui com o desmatamento na Amazônia. $O$ Estado de São Paulo, 26 January 2008. [online] URL: http://www.estado.com.br/editorias/2008/01/26/ ger-1.93.7.20080126.1.1.xml.

Escada, M. I .S., I. C. G. Vieira, S. Amaral, R. Araújo, J. B. da Veiga, A. P. D. Aguiar, I. Veiga, M. Oliveira, J. Gavina A. Carneiro Filho, P. M. Fearnside, A. Venturieri, F. Carrielo, M. Thales, T. S. Carneiro, A. M. V. Monteiro, and G. Câmara. 2005. Padrões e processos de ocupação nas novas fronteiras da Amazônia: o interflúvio do Xingu/Iriri. Estudos Avançados 19(54):9-23.

Faminow, M. D. 1998. Cattle, Deforestation and Development in the Amazon: An Economic and Environmental Perspective. CAB International, New York, New York, USA.

Fargione, J., J. Hill, D. Tilman, S. Polasky, and P. Hawthorne. 2008. Land clearing and the biofuel carbon debt. Science 319:1235-1238. 
Fearnside, P. M. 1979. The development of the Amazon rain forest: priority problems for the formulation of guidelines. Interciencia 4:338-343.

Fearnside, P. M. 1984. Land clearing behaviour in small farmer settlement schemes in the Brazilian Amazon and its relation to human carrying capacity. Pages 255-271 in A. C. Chadwick and S. L. Sutton, editors. Tropical rain forest: the Leeds Symposium. Leeds Philosophical and Literary Society, Leeds, UK.

Fearnside, P. M. 1985. Agriculture in Amazonia. Pages 393-418 in G. T. Prance and T. E. Lovejoy, editors. Key environments: Amazonia. Pergamon Press, Oxford, UK.

Fearnside, P. M. 1986a. Agricultural plans for Brazil's Grande Carajás Program: lost opportunity for sustainable development? World Development 14:385-409.

Fearnside, P. M. 1986b. Human carrying capacity of the Brazilian rainforest. Columbia University Press, New York, New York, USA.

Fearnside, P. M. 1987. Causes of deforestation in the Brazilian Amazon. Pages 37-61 in R. F. Dickinson, editor. The geophysiology of Amazonia: vegetation and climate interactions. John Wiley, New York, New York, USA.

Fearnside, P. M. 1989a. Ocupação humana de Rondônia: impactos, limites e planejamento. Relatórios de Pesquisa No. 5, Conselho Nacional de Desenvolvimento Científico e Tecnológico (CNPq), Brasília, DF, Brazil.

Fearnside, P. M. 1989b. Deforestation in the Amazon. Environment 31(7):4-5.

Fearnside, P. M. 1989c. Forest management in Amazonia: the need for new criteria in evaluating development options. Forest Ecology and Management 27:61-79.

Fearnside, P. M. 1995. Hydroelectric dams in the Brazilian Amazon as sources of "greenhouse" gases. Environmental Conservation 22:7-19.

Fearnside, P. M. 1997. Environmental services as a strategy for sustainable development in rural Amazonia. Ecological Economics 20:53-70.
Fearnside, P. M. 1998. Plantation forestry in Brazil: projections to 2050. Biomass and Bioenergy 15:437-450.

Fearnside, P. M. 1999a. Environmental and social impacts of wood charcoal in Brazil. Pages 177-182 in M. Prado, editor. Os Carvoeiros: the charcoal people of Brazil. Wild Images Ltda., Rio de Janeiro, RJ, Brazil.

Fearnside, P. M. 1999b. Social impacts of Brazil's Tucuruí Dam. Environmental Management 24:483495.

Fearnside, P. M. 2001a. Land-tenure issues as factors in environmental destruction in Brazilian Amazonia: the case of southern Pará. World Development 29:1361-1372.

Fearnside, P. M. 2001b. Soybean cultivation as a threat to the environment in Brazil. Environmental Conservation 28:23-38.

Fearnside, P. M. 2001c. Environmental impacts of Brazil's Tucuruí Dam: unlearned lessons for hydroelectric development in Amazonia. Environmental Management 27:377-396.

Fearnside, P. M. 2001d. Saving tropical forests as a global warming countermeasure: an issue that divides the environmental movement. Ecological Economics 39:167-184.

Fearnside, P. M. 2002. Avança Brasil: environmental and social consequences of Brazil's planned infrastructure in Amazonia. Environmental Management 30:748-763.

Fearnside, P. M. 2003. Deforestation control in Mato Grosso: a new model for slowing the loss of Brazil's Amazon forest. Ambio 32:343-345.

Fearnside, P. M. 2005. Deforestation in Brazilian Amazonia: history, rates and consequences. Conservation Biology 19:680-688.

Fearnside, P. M. 2006. Dams in the Amazon: Belo Monte and Brazil's hydroelectric development of the Xingu River Basin. Environmental Management 38:16-27.

Fearnside, P. M. 2007. Brazil's Cuiabá-Santarém (BR-163) Highway: the environmental cost of paving a soybean corridor through the Amazon. 
Environmental Management 39:601-614.

Fearnside, P.M. 2008. Amazon forest maintenance as a source of environmental services. Anais da Academia Brasileira de Ciências 80:101-114.

Fearnside, P.M., and R. I. Barbosa. 1996. Political benefits as barriers to assessment of environmental costs in Brazil's Amazonian development planning: the example of the Jatapu Dam in Roraima. Environmental Management 20:615-630.

Fearnside, P. M., and R. I. Barbosa. 2003. Avoided deforestation in Amazonia as a global warming mitigation measure: the case of Mato Grosso. World Resource Review 15:352-361.

Fearnside, P. M., and P. M. L. A. Graça. 2006. BR-319: Brazil's Manaus-Porto Velho Highway and the potential impact of linking the arc of deforestation to central Amazonia. Environmental Management 38:705-716.

Ferreira, L. V., E. Venticinque, and S. S. de Almeida. 2005. O desmatamento na Amazônia e a importância das áreas protegidas. Estudos Avançados 19(53):1-10.

Folha de São Paulo (FSP). 2007. Banco Mundial dá financiamento a gado na Amazônia. FSP, 9 March 2007, page A-18.

Geffray, C. 2002. Social, economic and political impacts of drug trafficking in the state of Rondônia, in the Brazilian Amazon. Pages 46-64 in C. Geffray, G. Fabre, and M. Shiray, editors. Globalisation, drugs and criminalisation: final research report from Brazil, China, India and Mexico. United Nations Educational and Scientific Organization (UNESCO), Paris, France. Three volumes.

Globo Video. 2008. Preço da soja bate recorde. [online] URL: http://video.globo.com/Videos/Player/ Noticias/0,.GIM779044-7823-PRECO+DA+SOJA+ BATE+RECORDE,00.html.

Greenpeace. 2001. Parceiros no crime: a extração ilegal de mogno, a Amazônia à mercê de "acordos entre cavalheiros". Greenpeace, Manaus, Amazonas, Brazil. [online] URL: http://www.greenpeace.org.br/ amazonia/pdf/report parceiros no crime.pdf.

Grieg-Gran, M., I. Porras, and S. Wunder. 2005. How can market mechanisms for forest environmental services help the poor? Preliminary lessons from Latin America. World Development 33:1511-1527.

Hecht, S. B. 1985. Environment, development and politics: capital accumulation in the livestock sector in eastern Amazonia. World Development 13:663684.

Hecht, S. B. 2005. Soybeans, development and conservation on the Amazon frontier. Development and Change 36:375-404.

Hecht, S. B., R. B. Norgaard, and C. Possio. 1988. The economics of cattle ranching in eastern Amazonia. Interciencia 13:233-240.

International Finance Corporation (IFC), Compliance Advisor/Ombudsman (CAO). 2005. CAO audit of IFC's environmental and social categorization of the Amaggi expansion project: final report, May 2005. CAO, IFC, Washington, D. C., USA. [online] URL: http://www.amazonia.org. br/arquivos/163786.pdf.

International Labor Organization (ILO). 2002. Não ao trabalho forçado. Relatório global do seguimento da declaração da OIT relativa a princípios e direitos fundamentais no trabalho, Conferência Internacional do Trabalho, $89^{\mathrm{a}}$ Reunião 2001, Relatório i (b), Secretaria Internacional do Trabalho, Geneba. Estação Gráfica Ltda., São Paulo, Brazil. [online] URL: http://www. oitbrasil.org.br/trabalho forcado/oit/relatorio/relat global. pdf.

John, L. 2002. Madeira amazônica é 75\% legal, mas ainda predatória. O Estado de São Paulo, 10 June 2002. [online] URL: http://www.amazonia.org. br/noticias/noticia.cfm?id=10388.

Karousakis, K. 2007. Incentives to reduce GHG emissions from deforestation: lessons learned from Costa Rica and Mexico. Organisation for Economic Co-operation and Development (OECD), Paris, France. [online] URL: http://www.oecd.org/dataoe cd/55/54/38523758.pdf.

Kianek, A. 2008. Preço do boi gordo deve permanecer em alta por mais dois anos. Folha de São Paulo, 22 January 2008, page B-14.

Kileen, T. J. 2007. A perfect storm in the Amazon wilderness: development and conservation in the 
context of the initiative for the integration of the regional infrastructure of South America (IIRSA). Conservation International, Arlington, Virginia, USA.

Kirby, K. R., W. F. Laurance, A. K. Albernaz, G. Schroth, P. M. Fearnside, S. Bergen, E. M. Venticinque, and C. da Costa. 2006. The future of deforestation in the Brazilian Amazon. Futures 38:432-453.

Laurance, W. F., A. K .M. Albernaz, G. Schroth, P. M. Fearnside, S. Bergen, E. M. Ventincinque, and C. da Costa. 2002. Predictors of deforestation in the Brazilian Amazon. Journal of Biogeography 29:737-748.

Laurance, W. F., M. A. Cochrane, S. Bergen, P. M. Fearnside, P. Delamônica, C. Barber, S. D'Angelo, and T. Fernandes. 2001. The future of the Brazilian Amazon. Science 291:438-439.

Lentini, M., A. Veríssimo, and D. Pereira. 2005. A expansão Madeireira na Amazônia. O Estado da Amazônia, No. 2, Instituto do Homem e Meio Ambiente da Amazônia (IMAZON), Belém, Pará, Brazil.

Machado, L. O. 2002. Drug trafficking and money laundering in the Amazon region: geoeconomic and geopolitical effects. Pages 208-235 in C. Geffray, G. Fabre, and M. Shiray, editors. Globalisation, drugs and criminalisation: final research report from Brazil, China, India and Mexico. United Nations Educational and Scientific Organization (UNESCO), Paris, France. Three volumes.

MacMillan, G. 1995. At the end of the rainbow? Gold, land and people in the Brazilian Amazon. Columbia University Press, New York, New York, USA.

Mahar, D. J. 1979. Frontier development policy in Brazil: a study of Amazonia. Praeger, New York, New York, USA.

Margulis, S. 2003. Causas do desmatamento na Amazônia brasileira. The World Bank, Brasília, DF, Brazil. [online] URL: http://siteresources.worldbank. org/BRAZILINPOREXTN/Resources/3817166-11 85895645304/4044168-1185895685298/010Causa sDesmatamentoAmazoniaBrasileira.pdf.

Mascolo, J. L. 1979. Um estudo economêtrico da pecuária de corte no Brasil. Revista Brasileira de Economia 33:65-105.

Mattos, M. M., and C. Uhl. 1994. Economic and ecological perspectives on ranching in the eastern Amazon. World Development 22:145-158.

Mertens, B., R. Poccard-Chapuis, M.-G. Piketty, A.-E. Laques, and A. Venturieri. 2002. Crossing spatial analyses and livestock economics to understand deforestation processes in the Brazilian Amazon: the case of Sao Felix do Xingu in South Pará. Agricultural Economics 27:269-294.

Mesquita, M. G. G. C., and E. G. Egler. 1979. Povoamento. Pages 56-79 in O. Valverde, editor. A organização do Espaço na faixa da transamazônica, Vol. 1: Introdução, Sudoeste Amazônico, Rondônia e Regiões Vizinhas, Instituto Brasileiro de Geografia e Estatística (IBGE), Rio de Janeiro, RJ, Brazil.

Moran, E. F. 1981. Developing the Amazon. Indiana University Press, Bloomington, Indiana, USA.

Morton, D. C., R. S. DeFries, Y. E. Shimabukuro, L. O. Anderson, E, Arai, F. del B. Espirito-Santo, R. Freitas, and J. Morisette. 2006. Cropland expansion changes deforestation dynamics in the southern Brazilian Amazon. Proceedings of the National Academy of Sciences 103:14637-14641.

Nepstad, D. C., S. Schwartzman, B. Bamberger, M. Santilli, D. Ray, P. Schlesinger, P. Lefebvre, A. Alencar, E. Prinz, G. Fiske, and A. Rolla. 2006. Inhibition of Amazon deforestation and fire by parks and indigenous lands. Conservation Biology 20:65-73.

Perz, S. G. 2002. Population growth and net migration in the Brazilian Legal Amazon, 19701996. Pages 107-129 in C. H. Wood and R. Porro, editors. Deforestation and land use in the Amazon. University Press of Florida, Gainesville, Florida, USA.

Pichonelli, M., and J. C. Magalhães. 2008. MT investirá R \$1 bilhão em frigoríficos. Folha de São Paulo, 27 January 2008, page A-22.

Pontes Júnior, F., E. Castro, R. Araújo, and M. A. Menezes. 2004. Terra do Meio: poder, violência e desenvolvimento. Idéas e Debates No. 7, Museu 
Paraense Emílio Goeldi (MPEG), Belém, Pará, Brazil.

Razera, A. 2005. Dinâmica do desmatamento em uma nova fronteira do sul do Amazonas: análise da pecuária de corte no município do Apuí. Thesis, Instituto Nacional de Pesquisas da Amazônia (INPA) and Universidade Federal do Amazonas (UFAM), Manaus, Amazonas, Brazil.

Rede GEOMA. 2003. Dinâmica territorial e socioambiental de áreas consolidadas: o caso da Região de Marabá. Rede GEOMA (Rede Temática de Pesquisa em Modelagem Ambiental da Amazônia), Ministério da Ciência e Tecnologia, Brasília, DF, Brazil.

Rocha, J. 2005. Trabalho escravo: presente, passado e futuro. Pages 237-269 in M. Torres, editor. Amazônia revelada: os descaminhos ao longo da BR-163. Conselho Nacional de Desenvolvimento Científico e Tecnológico (CNPq), Brasília, DF, Brazil.

Sánchez-Azofeifa, A., A. Pfaff, J. A. Robalino, and J. P. Boomhower. 2007. Costa Rica's payment for environmental services program: intention, implementation, and impact. Conservation Biology 21:1165-1173.

Sant'Anna, L. 2008. Queremos saber a serviço de quem o Inpe está mentindo. O Estado de São Paulo, 27 January 2008. [online] URL: http://www.amazo nia.org.br/noticias/noticia.cfm?id=260422.

Schmink, M., and C. H. Wood. 1992. Contested frontiers in Amazonia. Columbia University Press, New York, New York, USA.

Schneider, R. R., E. Arima, A. Veríssimo, P. Barreto, and C. Souza Júnior. 2000. Amazônia sustentável: limitantes e oportunidades para o desenvolvimento rural. World Bank, Brasília, DF and Instituto do Homem e Ambiente na Amazônia (IMAZON), Belém, Pará, Brazil.

Schönenberg, R. 2002. Drug trafficking in the Brazilian Amazon. Pages 172-207 in C. Geffray, G. Fabre, and M. Shiray, editors. Globalisation, drugs and criminalisation: final research report from Brazil, China, India and Mexico. United Nations Educational and Scientific Organization (UNESCO), Paris, France. Three volumes.
Schwartzman, S., A. Moreira, and D. Nepstad. 2000. Arguing tropical forest conservation: people versus parks. Conservation Biology 14:1370-1374.

Searchinger, T., R. Heimlich, R. A. Houghton, F. Dong, A. Elobeid, J. Fabiosa, S. Tokgoz, D. Hayes, and T.-H. Yu. 2008a. Use of U.S. croplands for biofuels increases greenhouse gases through emissions from land use change. Science 319:12381240.

Searchinger, T., R. Heimlich, R. A. Houghton, F. Dong, A. Elobeid, J. Fabiosa, S. Tokgoz, D. Hayes, and T.-H. Yu. 2008b. Supporting online material for use of U.S. Croplands for biofuels increases greenhouse gases through emissions from land use change. Science [online] URL: http://www.science mag.org/cgi/data/1151861/DC1/1.

Simmons, C. S. 2005. Territorializing land conflict: space, place, and contentious politics in the Brazilian Amazon. GeoJournal 64:307-317.

Smeraldi, R., and P. H. May. 2008. O Reino do Gado: uma nova fase da pecuarização da Amazônia. Amigos da Terra-Amazônia Brasileira, São Paulo, Brazil.

Smeraldi R., and J. A. de O. Veríssimo. 1999. Acertando o Alvo: consumo de madeira no mercado interno Brasileiro e promoção de certificação florestal. Amigos da Terra-Programa Amazônia, São Paulo, SP, IMAFLORA, Piracicaba, SP and IMAZON, Belém, Pará, Brazil.

Smith, N. J. H. 1982. Rainforest corridors: the transamazon colonization scheme. University of California Press, Berkeley, California, USA.

Soares-Filho, B. S., A. A. Alencar, D. C. Nepstad, G. C. Cerqueira, M. del C. V. Diaz, S. Rivero, L. Solórzano, and E. Voll. 2004. Simulating the response of land-cover changes to road paving and governance along a major Amazon highway: the Santarém-Cuiabá corridor. Global Change Biology 10:745-764.

Soares-Filho, B. S., D. C. Nepstad, L. M. Curran, G. C. Cerqueira, R. A. Garcia, C. A. Ramos, E. Voll, A. McDonald, P. Lefebvre, and P. Schlesinger. 2006. Modelling conservation in the Amazon Basin. Nature 440:520-523. 
Stickler, C. M., W.-L. Bartels, M. DiGiano, R. M. Veluci, K. J. Keefe, and W. Hart. 2005. An evaluation of International Finance Corporation financing of Grupo André Maggi. (Project $N^{o}$ 11344) in the soybean sector: environmental and social impact considerations. School of Natural Resources and Environment, University of Florida, Gainesville, Florida, USA. [online] URL: http://ww w.tropicalforests.ufl.edu/wft/documents/

IFC Amaggi Evaluation.pdf.

Sutton, A. 1994. Slavery in Brazil-a link in the chain of modernization. Anti-Slavery International, London, UK.

Turner, F. J. 1893. The significance of the frontier in American history. Proceedings of the American Historical Association for 1893: 199-222. (Reprinted in expanded form: Turner, F. J. 1996. The frontier in American history. Dover Publications, Mineola, New York, USA.).

Venturieri, A., A. P. D. Aguiar, A. M. V. Monteiro, A. Carneiro, D. Alves, G. Câmara, I. C. Vieira, I. Veiga, I. Escada, J. Veiga, J. Gavina, M. Thales, M. Oliveira, P. Fearnside, R. Araújo, S. A. Kampel, and T. G. Carneiro. 2004. Sumário executivo da missão de campo na região de São Félix do Xingu/Iriri, 13 a 18 de outubro de 2004. Dinâmica de uso e ocupação do território, dinâmica de população e assentamentos humanos e modelagem computacional. Dinâmica territorial da frente de ocupação de São Félix do Xingu-Iriri : Subsídios para o desenho de políticas emergenciais de contenção do desmatamento. Secretaria de Políticas e Programas de Pesquisa e Desenvolvimento: Rede GEOMA, Ministério da Ciência e Tecnologia (MCT), Brasília, DF, Brazil. [online] URL: http://p hilip.inpa.gov.br/publ livres/2004/Doc Sumario E xec Ministro Xinguri Nov2004 Final.pdf.

Viana, V., and M. T. Campos. 2007. Bolsa floresta: recompensa para quem conserva a floresta em Pé. Secretaria do Estado do Meio Ambiente e Desenvolvimento Sustentável (SDS), Manaus, Amazonas, Brazil.

Walker R., E. Moran, and L. Anselin. 2000. Deforestation and cattle ranching in the Brazilian Amazon: external capital and household processes. World Development 28:683-699.

Zanini, F., and M. C. Cabral. 2008. Governo controla $81 \%$ das cidades líderes no desmate. Folha de São Paulo, 29 January 2008, page A-15. 